\title{
PENGARUH PENGGUNAAN MODEL PEMBELAJARAN CONTEXTUAL TEACHING AND LEARNING (CTL) TERHADAP KEAKTIFAN BELAJAR PESERTA DIDIK PADA MATA PELAJARAN AQIDAH AKHLAK DI MADRASAH TSANAWIYAH TASIKMALAYA
}

\author{
Salma Sopia Adistiani ${ }^{1}$, Nana Suryana ${ }^{2}$, Nita Anjung Munggaran ${ }^{3}$ \\ Institut Agama Islam Latifah Mubarokiyah, Tasikmalaya, Indonesia \\ adistianisofiasalma@gmail.com, suryanaaljoe@gmail.com, \\ bima.dzakiramunggaran@gmail.com
}

\begin{abstract}
Abstrack
This study aims to determine the influence of Contextual Teaching and Learning learning on the learning activeness of students in Aqidah Morals in MTs Puteran, Puteran Village, Pagerageung District, Tasikmalaya. The method used in this research is descriptive method with quantitative approach. To collect the data needed techniques such as questionnaires, interview guidelines and observation guidelines. Based on the results of data processing, it was found that Contextual Teaching and Learning in MTs Puteran was classified as sufficient (a score of 32,88 was obtained, above the classification of 31,74 to 36,11 with sufficient criteria). While the learning activeness of students in MTs Puteran is relatively low (obtained a value of 29,5, is on the interpretation scale between 25,75 to 30,5 with low criteria). And the effect of Contextual Teaching and Learning learning on the learning activeness of students in MTs Puteran has a positive and significant effect with sufficient categories, it is proven that $r s=0,57$ is at an interval of 0,41 to 0,60 and $t_{\text {count }} 3,26$ $\geq t_{\text {table }}$ 1,72. Contextual Teaching and Learning determines the learning activeness of students by $32,49 \%$ while the remaining $67,51 \%$ is thought to be determined by other factors.
\end{abstract}

Keywords: Learning; Contextual Teaching and Learning; Active Learning; Aqeedah Morals; Students

Abstrak

Penelitian ini bertujuan untuk mengetahui pengaruh pembelajaran Contextual Teaching and Learning terhadap keaktifan belajar peserta didik pada mata pelajaran Aqidah Akhlak di MTs Puteran Desa Puteran Kecamatan Pagerageung Tasikmalaya. Metode yang dilakukan dalam penelitian ini adalah metode deskriptif dengan pendekatan kuantitatif. Untuk mengumpulkan data yang diperlukan digunakan teknik-teknik seperti angket, pedoman wawancara dan pedoman observasi. Berdasarkan hasil pengolahan data diperoleh bahwa pembelajaran Contextual Teaching and Learning di MTs Puteran tergolong cukup (diperoleh nilai sebesar 32,88, berada pada klasifikasi diatas 31,74 sampai 36,11 dengan kriteria cukup). Sedangkan keaktifan belajar peserta didik di MTs Puteran tergolong rendah (diperoleh nilai sebesar 29,5, berada pada skala penafsiran antara 25,75 sampai 30,5 dengan kriteria rendah). 
Dan pengaruh pembelajaran Contextual Teaching and Learning terhadap keaktifan belajar peserta didik di MTs Puteran mempunyai pengaruh positif dan signifikan dengan kategori cukup, terbukti $\mathrm{rs}=0,57$ berada pada interval $0,41-0,60$ serta $\mathrm{t}_{\text {hitung }} 3,26 \geq \mathrm{t}_{\text {tabel }} 1,72$. Pembelajaran Contextual Teaching and Learning menentukan keaktifan belajar peserta didik sebesar 32,49\% sedangkan sisanya $67,51 \%$ diduga ditentukan oleh faktor lain.

Kata Kunci: Pembelajaran; Contextual Teaching and Learning; Keaktifan Belajar; Aqidah Akhlak; Peserta Didik 


\section{A. PENDAhULUAN}

Mengajar dilakukan oleh guru dan belajar dilakukan oleh peserta didik. Saat belajar, khususnya di sekolah seharusnya terjadi komunikasi antara peserta didik dengan guru. Komunikasi antara guru kepada peserta didik dan peserta didik kepada peserta didik atau terjadi komunikasi dua arah. Komunikasi dua arah dilakukan agar guru tidak mendominasi pada saat pembelajaran berlangsung tetapi mengarahkan dan membimbing agar peserta didik aktif berperan untuk memperoleh pemahamannya terhadap semua informasi yang guru berikan dalam pembelajaran. Adanya perubahan paradigma pendidikan saat ini menuntut adanya perubahan proses pembelajaran didalam kelas. Peran guru saat ini diarahkan untuk menjadi fasilitator yang dapat membantu peserta didik dalam belajar, bukan hanya sekedar menyampaikan materi saja sehingga peserta didik dapat berperan aktif dalam mengolah bahan ajar yang diberikan yang diberikan oleh guru sesuai kemampuan masing-masing.

Masih banyak pendidikan di sekolah pada praktiknya masih berfokus pada guru. Sedangkan peserta didik hanya pasif, tidak berperan aktif ketika pembelajaran berlangsung. Hal ini terlihat dari aktivitas peserta didik yang terbatas hanya hadir dikelas, mendengarkan guru dan mencatat tanpa bertanya maupun menjawab pertanyaan yang diajukan oleh guru dan juga berisik apabila guru memberikan soal latihan.

Ditemukan bahwa masih terdapat peserta didik yang hanya mendengarkan penjelasan dari guru, menulis apa yang disampaikan oleh guru dan kemudian menyelesaikan soal-soal latihan yang diberikan oleh guru selama proses pembelajaran berlangsung tanpa berinisiatif dengan melakukan konfirmasi dan bertanya terlebih dahulu apabila memiliki pertanyaan mengenai materi yang diajukan oleh guru.

Hal seperti ini cenderung membuat peserta didik menjadi malas, tidak antusias dalam mengikuti pembelajaran. Padahal, semakin tinggi aktifitas peserta didik dalam pembelajaran maka akan semakin mempercepat pemahaman peserta didik terhadap materi pelajaran sehingga dapat menunjang keberhasilan pembelajaran. Selain itu juga, keaktifan belajar peserta didik dalam proses pembelajaran akan menyebabkan interaksi yang tinggi antara guru dengan peserta didik ataupun dengan peserta didik itu sendiri. Interaksi tersebut akan menjadi tinggi sehubungan dengan adanya keaktifan belajar peserta didik, semakin tinggi keaktifan belajar maka semakin tinggi juga interaksi peserta didik. Peserta didik jadi saling mempengaruhi dan saling memberikan pendapat satu sama lain. Hal ini akan mengakibatkan suasana kelas menjadi kondusif, yang dimana ciri-ciri kelas yang kondusif yaitu tenang, dinamis, tertib, suasana saling menghargai, saling mendorong, kreatifitas tinggi, persaudaran yang kuat, saling berinteraksi dengan baik dan bersaing segat untuk kemajuan.

Keaktifan belajar peserta didik merupakan unsur dasar yang penting bagi keberhasilan proses pembelajaran. Keaktifan adalah kegiatan yang bersifat fisik maupun mental, yaitu berbuat dan berfikir sebagai suatu rangkaian yang tidak dapat dipisahkan.

Di dalam proses belajar mengajar, guru tidak akan mampu menghasilkan proses pembelajaran yang baik apabila tidak didukung oleh keaktifan peserta didik dalam proses belajar. Apabila dalam proses belajar mengajar tidak didukung oleh 
keaktifan belajar peserta didik, maka dampak yang akan dihasilkan adalah kegagalan dalam pembelajaran.

Upaya yang dapat dilakukan untuk menghindari kegagalan dalam proses pembelajaran adalah dengan menerapkan model pembelajaran. Menurut penelitian model pembelajaran yang dapat meningkatkan keaktifan belajar peserta didik adalah dengan penerapan model pembelajaran Contextual Teaching and Learning (CTL). Model ini merupakan suatu model pembelajaran yang menekankan kepada proses keterlibatan peserta didik secara penuh untuk dapat menemukan materi yang dipelajari dan menghubungkannya dengan situasi kehidupan nyata sehingga mendorong peserta didik untuk dapat menerapkannya dalam kehidupan mereka (Wina Sanjaya, 2013 : 255).

Perlu adanya pembaharuan-pembaharuan pembelajaran yang mengarahkan proses pembelajaran agar peserta didik dapat selalu aktif, usaha meningkatkan keaktifan belajar peserta didik di dalam kelas sangat penting untuk dilakukan oleh para guru. Untuk itu dalam pembelajaran seorang guru harus menggunakan metode, model pembelajaran dan strategi yang tepat agar apa yang dipelajari oleh peserta didik dapat dimengerti dengan baik sehingga peserta didik akan aktif di dalam kelas, salah satunya adalah model pembelajaran Contextual Teaching and Learning (CTL). Penelitian ini bertujuan untuk mengaktifkan peserta didik dengan menggunakan model pembelajaran kontekstual dan penelitian ini dikatakan penting karena model pembelajaran yang guru berikan dapat dijadikan tolak ukur keberhasilan belajar atau kegagalan pada peserta didik selama proses pembelajaran berlangsung yang dapat dilihat dari keaktifan peserta didik (Mutiara, Vol.03 No.01 : 2015).

Salah satu model pembelajaran yang dapat memberdayakan peserta didik, yakni pembelajaran dengan menggunakan Contextual Teaching and Learning (CTL). Dengan pendekatan CTL, akan terjalin suasana belajar yang mengutamakan kerja sama, saling menunjang, menyenangkan, tidak membosankan, (Nur Hadiyanta, Vol.43 No.1 : 2013). belajar dengan bergairah, pembelajaran terintegrasi, menggunakan berbagai sumber, peserta didik aktif, sharing dengan teman, peserta didik kritis, guru kreatif. Pembelajaran berlangsung secara alamiah dalam bentuk kegiatan peserta didik bekerja dan mengalami, bukan transfer pengetahuan dari guru. Peserta didik dapat mengkontruksikan sendiri pengetahuannya, menemukan sendiri konsep-konsep materi yang sudah dihadapi

Dengan penerapan model ini dalam pembelajaran maka peserta didik dituntut untuk aktif dalam proses pembelajaran dan aktifnya peserta didik dalam pembelajaran maka proses pembelajaran akan berhasil. Pembelajaran ini juga akan semakin menguatkan semangat anak untuk belajar secara mandiri. Sehingga terjadinya kesadaran individu dan kolektif dalam diri siswa untuk belajar secara aktif di kelas.

Berdasarkan hasil observasi realita dan kondisi yang ada di MTs Puteran bahwa dalam proses pembelajaran Aqidah Akhlak masih banyaknya peserta didik yang kurang aktif dalam proses pembelajaran, hal ini dapat dilihat dari kejadian dikelas, peserta didik cenderung pasif dalam proses pembelajaran, rendahnya partisipasi peserta didik dalam kegiatan diskusi, masih banyak peserta didik yang tidak mengerjakan tugas. 
Dari kejadian di atas menyebabkan proses pembelajaran Aqidah Akhlak yang dilaksanakan tidak berjalan dengan baik masih banyak peserta didik yang kurang aktif dalam pembelajaran, sementara dalam proses pembelajaran guru sudah menggunakan metode, media dan pendekatan pembelajaran. Kurangnya keaktifan peserta didik dalam pembelajaran menghambat proses pembelajaran yang pada akhirnya berdampak kepada tidak tercapainya tujuan pembelajaran.

Adapun rumusan masalah dalam penelitian ini adalah (1) Bagaimana penggunaan model pembelajaran Contextual Teaching and Learning (CTL) di MTs Puteran?, (2) Bagaimana keaktifan belajar peserta didik pada mata pelajaran Aqidah Akhlak di MTs Puteran?, (3) Bagaimana pengaruh penggunaan model pembelajaran Contextual Teaching and Learning (CTL) terhadap keaktifan belajar peserta didik pada mata pelajaran Aqidah Akhlak di MTs Puteran?.

Berdasarkan rumusan masalah tersebut, maka tujuan penelitian yang dicapai adalah untuk mengetahui dan menganalisis (1) Penggunaan model pembelajaran Contextual Teaching and Learning (CTL) di MTs Puteran, (2) Keaktifan belajar peserta didik pada mata pelajaran Aqidah Akhlak di MTs Puteran, (3) Pengaruh penggunaan model pembelajaran Contextual Teaching and Learning (CTL) terhadap keaktifan belajar peserta didik pada mata pelajaran Aqidah Akhlak di MTs Puteran.

\section{B. METODE}

Metode yang digunakan dalam penelitian ini adalah metode deskriptif dengan pendekatan kuantitatif. Metode deskriptif adalah metode penelitian yang berupaya untuk mengungkapkan keadaan atau kondisi yang terjadi saat sekarang dengan mempertimbangkan keadaan masa lampau, sehingga dapat diperoleh deskripsi atau gambaran secara sistematis, faktual, dan akurat mengenai fakta-fakta serta hubungan antar fenomena yang diteliti. (Wawan, t.t : 5).

Penelitian ini dilaksanakan sejak 1 Mei 2020 sampai dengan 30 Mei 2020 yang berlokasi di Madrasah Tsanawiyah Puteran Kecamatan Pagerageung Kabupaten Tasikmalaya.

Instrumen penelitian yang digunakan pada penelitian ini yaitu observasi, wawancara, dan angket. Adapun yang menjadi populasi dalam penelitian ini adalah seluruh peserta didik Madrasah Tsanawiyah Puteran yaitu berjumlah 86 peserta didik. Teknik pengambilan sampel yang digunakan dalam penelitian ini adalah teknik purposive sampling, "Purposive sampling adalah teknik penentuan sampel dengan pertimbangan tertentu" (Sugiyono, 2010 : 85). Alasan pemilihan teknik sampling tersebut adalah karena peserta didik kelas VIII diangap sebagai peserta didik yang lebih dewasa dan paling tahu tentang apa yang peneliti harapkan serta bisa lebih mudah diajak kerja sama dalam penelitian, sehingga akan memudahkan peneliti untuk mengambil sampel penelitian.

Dan jumlah sampel yang akan diambil dalam penelitian ini yaitu sebanyak 24 peserta didik. 
Teknik pengumpulan data yang digunakan yaitu berupa angket. Angket digunakan untuk mengumpulkan data dan memperoleh informasi mengenai model pembelajaran Contextual Teaching and Learning (CTL) dan keaktifan belajar peserta didik. Dalam penelitian ini menggunakan angket tertutup, dimana responden diberikan alternatif jawaban, sehingga mereka tinggal memilih alternatif jawaban yang telah disediakan tersebut.

Teknik analisis data yang digunakan terdiri dari dua tahapan yaitu: Analisis deskriptif, digunakan untuk mendeskripsikan masing-masing variabel $\mathrm{X}$ dan Y. Analisis korelasi, digunakan untuk mengetahui besarnya pengaruh masing-masing komponen variabel bebas, yaitu diketahui dengan menggunakan koefisien korelasi rank spearman (rs).

\section{HASIL DAN PEMBAHASAN}

\section{Hasil}

Berdasarkan hasil analisis data tentang pengaruh penggunaan model pembelajaran Contextual Teaching and Learning (CTL) terhadap keaktifan belajar peserta didik pada mata pelajaran Aqidah Akhlak yang penulis dapatkan dari hasil penyebaran angket di MTs Puteran. Maka didapatkan beberapa kesimpulan yang akan penulis bahas, yaitu sebagai berikut :

a. Hasil penelitian menunjukan bahwa nilai rataan untuk pembelajaran Contextual Teaching and Learning (variabel $\mathrm{X}$ ) diperoleh nilai sebesar 32,88. Angka tersebut berada di atas 31,74 sampai 36,11 berada pada klasifikasi baik. Berdasarkan hasil pengujian tersebut dapat dijelaskan bahwa pembelajaran Contextual Teaching and Learning di MTs Puteran pada mata pelajaran Aqidah Akhlak mempengaruhi keaktifan belajar peserta didik . Sebab, di dalam proses pembelajaran Contextual Teaching and Learning di MTs Puteran pada mata pelajaran Aqidah Akhlak, indikator-indikator dari pembelajaran Contextual Teaching and Learning sudah tertanam dalam jiwa peserta didik.

Akhir-akhir ini pembelajaran Contextual Teaching and Learning (CTL) merupakan salah satu pembelajaran yang banyak dibicarakan orang. Contextual Teaching and Learning (CTL) merupakan strategi pembelajaran yang melibatkan peserta didik secara penuh dalam proses pembelajaran. Peserta didik di dorong untuk beraktivitas mempelajari materi pelajaran sesuai dengan topik yang akan dipelajarinya. Belajar Contextual Teaching and Learning (CTL) bukan hanya sekedar mendengarkan dan mencatat, tetapi belajar sebagai proses pengalaman secara langsung. Melalui proses pengalaman itu diharapkan perkembangan peserta didik terjadi secara utuh, tidak berkembang dalam aspek kognitif saja, tetapi juga aspek afektif dan psikomotor.

Dalam kelas kontekstual, tugas guru adalah membantu peserta didik mencapai tujuannya. Maksudnya, guru lebih banyak berurusan dengan pendekatan daripada memberi informasi. Tugas guru mengelola kelas sebagai sebuah tim yang bekerja sama untuk menemukan sesuatu yang baru bagi peserta 
didik. Sesuatu yang baru datang dari menemukan sendiri bukan dari apa kata guru. Begitulah peran guru di kelas yang dikelola dengan pendektan kontekstual.

Johson dalam Kunanda (2007 : 274) dalam buku implementasi kurikulum tingkat satuan pendidikan dan guru profesional, menyatakan bahwa :

Pembelajaran Contextual Teaching and Learning (CTL) adalah suatu proses pendidikan yang bertujuan membantu peserta didik melihat makna dalam bahan pelajaran yang mereka pelajari dengan cara menghubungkannya dengan konteks kehidupan mereka sehari-hari, yaitu dengan konteks lingkungan pribadinya, sosialnya dan budayanya.

Sedangkan menurut Ramayulis (2012 : 255) pembelajaran Contextual Teaching and Learning (CTL) adalah suatu konsepsi belajar mengajar yang membantu pendidik menghubungkan isi pelajaran dengan situasi dunia nyata dan memotivasi peserta didik membuat hubungan-hubungan antara pengetahuan dan aplikasinya dalam kehidupan peserta didik sebagai anggota keluarga masyarakat dan pekerjaan serta meminta ketekunan belajar.

Dari beberapa pengertian di atas dapat disimpulkan bahwa pembelajaran Contextual Teaching and Learning (CTL) adalah pendekatan pembelajaran yang dilakukan pendidik dalam proses pembelajaran agar peserta didik dapat menghubungkan atau mengaitkan antara materi pembelajaran dengan kenyataan yang peserta didik temukan dalam kehidupan sehari-hari, sehingga peserta didik dapat menerapkan materi pembelajaran yang di pelajarinya dalam kehidupannya.

CTL memiliki tujuh asas. Asas-asas ini yang melandasi pelaksanaan proses pembelajaran dengan menggunakan CTL. Ketujuh asas tersebut, yaitu :

1) Kontruktivisme (Contructivism)

Kontruktivisme adalah landasan berpikir pembelajaran atau contextual yang mengatakan bahwa pengetahuan dibangun oleh manusia setahap demi setahap yang hasilnya diperluas melalui konteks yang terbatas (sempit) dan tidak sekoyong-koyong. Pengetahuan bukanlah seperangkat fakta-fakta, konsep atau kaidah yang siap untuk diambil dan diingat. Manusia harus mengkontruksi pengetahuan itu dan memberi makna melalui pengalaman nyata. Peserta didik perlu dibiasakan untuk memecahkan masalah, menemukan sesuatu yang berguna bagi dirinya dan bergelut dengan ide-ide. Oleh karena itu pendidik perlu memfasilitasi proses tersebut dengan.

a) Menjadikan pengetahuan bermakna dan relevan bagi peserta didik.

b) Memberi kesempatan peserta didik menemukan dan menerapkan idenya sendiri.

c) Menyadarkan peserta didik agar menerapkan strategi mereka sendiri dalam belajar.

2) Menemukan (Inquiry)

Inquiry artinya proses pembelajaran didasarkan pada pencarian dan penemuan melalui proses berpikir secara sistematis. Secara umum, proses inquiry dapat dilakukan melalui beberapa langkah, yaitu merumuskan 
masalah, mengajukan hipotesis, mengumpulkan data, menguji hipotesis berdasarkan data yang ditemukan dan membuat kesimpulan.

3) Bertanya (Questioning)

Bertanya merupakan strategi utama pembelajaran berbasis contextual. Bertanya dalam pembelajaran sebagai kegiatan pendidik untuk mendorong, membimbing dan meilai kemampuan berfikir peserta didik. Bagi peserta didik kegiatan bertanya merupakan bagian penting dalam melaksanakan pembelajaran yang berbasis inquiry, yaitu menggali informasi, mengkonfirmasikan apa yang sudah diketahui dan mengarahkan perhatian pada aspek yang belum diketahuinya.

4) Masyarakat Belajar (Learning Community)

Hasil belajar sebaiknya diperoleh dari kerja sama semua peserta didik dan antara peserta didik dengan orang lain. Hal ini berarti bahwa hasil belajar bisa diperoleh dengan sharing antar teman, antar kelompok dan antar yang tahu kepada yang tidak tahu, baik di dalam maupun di luar kelas.

5) Pemodelan (Modelling)

Peserta didik dalam belajar harus mengidentifikasi diri dengan model yang akan ditirunya. Prinsip-prinsip modelling yang bisa dipertimbangkan dalam pembelajaran CTL adalah sebagai berikut:

a) Pengetahuan dan keterampilan diperoleh dengan mantap apabila ada contoh yang bisa ditiru.

b) Contoh bisa diperoleh langsung dan para ahli.

c) Model atau contoh bisa berupa cara mengoprasikan sesuatu, contoh hasil karya atau model penampilan.

6) Refleksi (Refection)

Refleksi adalah perenungan kembali atas pengetahuan yang baru dipelajari. Peserta didik harus menyadari bahwa pengetahuan yang baru diperolehnya merupakan revisi dan pengayaan terhadap pengetahuan yang sudah ada padanya.

7) Penilaian Nyata (Authentic Assessment)

Penilaian authentic adalah proses pengumpulan berbagai data yang dapat memberikan informasi tentang perkembangan pengalaman peserta didik. Penilaian authentic diarahkan pada proses mengamati, menganalisis dan menafsirkan data yang telah terkumpul ketika atau dalam proses pembelajaran sedang berlangsung, bukan semata-mata pada hasil pembelajaran saja (Ramayulis, $2012: 258-261$ ).

Dengan adanya asas Contextual Teaching and Learning (CTL) pembelajaran dan pengajaran melibatkan para peserta didik dalam aktifitas yang membantu mereka mengaitkan pelajaran dengan kehidupan nyata. Dengan 
mengaitkan keduanya ketika mereka menemukan pengetahuan baru, menemukan permasalahan, pertanyaan-pertanyaan dengan tujuan untuk mengembangkan rasa ingin tahu, bekerja kelompok untuk melakukan diskusi, memberi contoh yang baik, refeksi atas kegiatan yang dilakukan, evaluasi atau penilaian, dengan cara ini mereka menemukan makna belajar. Dengan adanya ke tujuh asas tersebut dapat memodifikasi sesuai dengan kebutuhan peserta didik.

Di dalam model pembelajaran Contextual Teaching and Learning terdapat kelebihan dan kelemahan, diantaranya :

a) Model pembelajaran Contextual Teaching and Learning adalah konsep yang membantu guru mengaitkan antara materi pembelajaran dengan situasi dunia nyata dan mendorong peserta didik membuat hubungan antara pengetahuan yang dimilikinya dengan penerapannya dalam kehdiupan sehari-hari. Kelebihan dalam pembelajaran Contextual Teaching and Learning (CTL) antara lain sebagai berikut :

(1) Pembelajaran lebih bermakna, artinya peserta didik melakukan sendiri kegiatan berhubungan dengan materi yang ada sehingga peserta didik dapat memahaminya sendiri.

(2) Pembelajaran lebih produktif dan mampu menumbuhkan penguatan konsep kepada peserta didik karena pembelajaran Contextual Teaching and Learning menuntun peserta didik menemukan sendiri bukan menghafal.

(3) Menumbuhkan kebenaran peserta didik mengemukakan pendapat tentang materi yang dipelajari.

(4) Menumbuhkan rasa ingin tahu tentang materi yang dipelajari dengan bertanya kepada guru.

(5) Menumbuhkan kemampuan dalam bekerja sama dengan teman yang lain untuk memecahkan masalah yang ada.

(6) Peserta didik dapat membuat kesimpulan sendiri kegiatan pembelajaran (Raja, Vol.06 No.02 : 2017).

b) Selain mempunyai kelebihan, pembelajaran CTL juga mempunyai kelemahan, diantaranya sebagai berikut :

(1) Pemilihan informasi atau materi di kelas didasarkan pada kebutuhan peserta didik, padahal di dalam kelas itu tingkat kemampuan peserta didiknya berbeda-beda sehingga guru akan kesulitan dalam menentukan materi pelajaran karena tingkat pencapaiannya tadi tidak sama.

(2) Tidak efesien karena membutuhkan waktu yang agak lama dalam proses belajarengajar.

(3) Dalam proses pembelajaran dengan model CTL akan nampak jelas antara peserta didik yang memiliki kemampuan tinggi dan peserta didik yang memiliki kemampuan rendah, kemudian menimbulkan rasa tidak percaya diri bagi peserta didik yang kemampuannya rendah.

(4) Bagi peserta didik tertinggal dalam proses pembelajaran dengan CTL ini akan terus tertinggal dan sulit untuk mengejar ketinggalan karena dalam 
pembelajaran ini kesuksesan peserta didik tergantung dari keaktifan dan usaha sendiri, jadi peserta didik dengan baik mengikuti setiap pembelajaran dengan model ini tidak akan menunggu teman yang tertinggal dan mengalami kesulitan.

(5) Tidak semua peserta didik dapat dengan mudah menyesuaikan diri dan mengembangkan kemampuan yang dimiliki dengan penggunaan model ini.

(6) Kemampuan setiap peserta didik berbeda-beda dan peserta didik yang memiliki kemampuan intelektual yang tinggi namun sulit untuk mengapresiasikannya dalam bentuk lisan akan mengalami kesulitan sebab CTL ini lebih mengembangkan ketemrampilan dan kemampuan soft skill dari pada kemampuan intelektualnya.

(7) Pengetahuan yang didapat oleh setiap peserta didik akan berbeda-beda dan tidak merata.

(8) Peran guru tidak terlalu tampak penting lagi, karena dalam CTL ini peran guru hanya sebagai pengarah dan pembimbing. Oleh karena itu lebih menuntit peserta didik untuk aktif dan berusaha sendiri mencari infomasi, mengamati fakta dan menemukan pengetahuan-pengetahuan baru dilapangan (Trianto, $2010: 110)$.

b. Perolehan nilai rataan untuk variabel Y mengenai keaktifan belajar peserta didik diperoleh sebesar 29,5 berada pada skala penafsiran antara 25,75 sampai 30,5 berdasarkan hasil penafsiran tersebut keaktifan belajar peserta didik di MTs Puteran dalam mata pelajaran Aqidah Akhlak adalah rendah.

Proses pembelajaran pada hakekatnya untuk mengembangkan aktivitas dan kreatifitas peserta didik melalui berbagai interaksi dan pegalaman belajar. Keaktifan belajar peserta didik merupakan unsur dasar yang penting bagi keberhasilan proses pembelajaran. Keaktifan adalah kegiatan yang bersifat fisik maupun mental, yaitu berbuat dan berfikir sebagai suatu rangkaian yang tidak dapat dipisahkan.

Maka, pembelajaran aktif dimaksudkan untuk mengoptimalkan penggunaan semua potensi yang dimiliki peserta didik, sehingga semua peserta didik dapat mencapai hasil belajar yang memuaskan sesuai dengan karakteristik pribadi yang mereka miliki. Disamping itu, pembelaran aktif juga dimaksudkan untuk menjaga perhatian peserta didik agar tetap tertuju pada proses pembelajaran (Hartono, $2008: 20$ ).

Keaktifan peserta didik dalam proses pembelajaran akan dapat merangsang dan mengembangkan bakat yang dimilikinya, berpikir kritis dan dapat memecahkan masalah-masalah kehidupan sehari-hari.

Sedangkan menurut Syaiful Sagala (2010 : 59) pembelajaran aktif dimaksudkan bahwa dalam pelaksanaan pembelajaran guru harus menciptakan suasana pembelajaran yang dinamis penuh aktifitas. Sehingga peserta didik aktif untuk bertanya, mempertanyakan dan mengemukakan gagasan. Belajar 
merupakan proses aktif dari peserta didik dalam membangun pengetahuan dan keterampilan.

Berdasarkan pengertian belajar aktif diatas, maka dapat disimpulkan bahwa pembelajaran aktif adalah suatu pembelajaran yang memberikan kesempatan kepada peserta didik untuk berperan lebih aktif dalam proses pembelajaran diantaranya dalam hal mencari informasi, mengolah infomasi dan menyimpulkan untuk kemudian diterapkan dan dipraktikan dalam lingkungan peserta didik.

Keaktifan belajar merupakan hasil yang diperoleh peserta didik selama belajar disekolah, yang merupakan perpaduan dari tiga ranah tersebut, yang menyangkut ranah kognitif, ranah afektif dan ranah psikomotor.

Peraturan Pemerintah Nomor 19 Tahun 2005 tentang Standar Nasional Pendidikan pada pasal 19 , ayat 1 mengamanatkan bahwa proses pembelajaran pada satuan pendidikan diselenggarakan secara interaktif, inspiratif, menyenangkan, menantang, memotivasi peserta didik untuk berpartisipasi aktif, secara memberikan ruang yang cukup bagi prakarsa, kreatifitas dan kemandirian sesuai dengan bakat, minat dan perkembangan fisik serta psikologis peserta didik.

Berdasarkan kutipan regulasi pendidikan tersebut, dapat dipahami secara jelas bahwa proses pendidikan dan pembelajaran pada satuan pendidikan manapun, secara yuridis formal dituntut harus diselenggarakan secara aktif, inovatif, kreatif, dialogis, demokratis dan dalam suasana yang mengesankan dan bermakna bagi peserta didik. Dengan kata lain bahwa perundangan dan peraturan pendidikan yang berlaku di Indonesia, mengindikasikan pentingnya diterapkan strategi pembelajaran yang memperdayakan peserta didik di kelas.

Suatu keaktifan proses belajar mengajar yang mampu memperdayakan peserta didik di kelas, dapat diukur salah satunya melalui pengamatan terhadap kegiatan peserta didik dalam mengikuti pelajaran dikelas. Adapun indikator keaktifan belajar ini meliputi.

1) Aktif belajar yang terjadi dengan proses mengalami. Artinya proses mengalami disini adalah peserta didik membimbing untuk melakukan sendiri mengikitu belajar, keberanian menjawab pertanyaan teman, keberanian mencoba mempraktekan materi yang sedang dipelajarinya. Adapun aspek yang dapat dinilai dalam aspek aktif beajar mengalami sendiri, adalah kejelasan dalam mempresentasikan apa yang mereka pelajari saat ini.

2) Aktif belajar yang terbentuk dalam transaksi atau peristiwa belajar aktif. Peristiwa belajar, merupakan kegiatan yang memerlukan konsentrasi yang maksimal dari peserta didik yang sedang belajar. Peserta didik yang pasif, kelihatan hanya mengamati apa yang dilakukan oleh guru, teman atau melihat-lihat saja. Sehingga dalam mengikuti pembeajaran ini peserta didik tersebut kelihatan kurang aktif. Hasil yang diperoleh dari peserta didik tersebut adalah sebatas pada tahu apa yang dilihatnya. Maka faktor yang dapat dinilai dari aspek belajar yang terbentuk dalam transaksi atau peristiwa 
belajar aktif dalam penelitian ini adalah ditinjau dari segi kedalaman informasi yang mereka dapatkan ketika belajar.

3) Keaktifan belajar terjadi melalui proses mengatasi masalah sehingga terjadi proses pemecahan masalah. Ketika melakukan proses belajar khusunya dalam materi praktek, maka diantara peserta didik ada yang kurang memahami maksud dari rekannya. Sehingga disitu akan terjadi interaksi edukatif antara peserta didik yang satu dengan yang lainnya. Faktor yang dapat dinilai adalah keaktifan dalam mengutarakan ide-ide baru, guna menyelesaikan masalah yang muncul saat itu. Biasanya diawali dari cara kerja dari pelaksanaan praktek itu, berlanjut pada cara melakukannya dan diakhiri dengan membuat sebuah pelaporan kegiatan maka jika terjadi masalah-masalah yang muncul diantara kelompok belajar, maka mereka akan berusaha mengatasi sendiri, untuk mendapatkan hasil yang maksimal. Adapun aspek yang dapat dinilai terkait tentang keaktifan belajar terjadi melalui proses mengatasi masalah adalah kejelasan dalam berdiskusi (Sinar, $2018: 15-20)$.

Menurut Oemar Hamalik (2005 : 91) mengemukakan sejumlah manfaat atau kegunaan dari kegiatan pembelajaran aktif, diantara lain:

a) Peserta didik mencari pengalaman sendiri dan langsung mengalami sendiri.

b) Berbuat sendiri akan mengembangkan seluruh aspek kepribadian peserta didik.

c) Memupuk kerja sama yang harmonis di kalangan para peserta didik yang pada gilirannya dapat memperancarkerja kelompok.

d) Peserta didik belajar dan bekerja berdasarkan minat dan kemampuan sendiri, sehingga sangat bermanfaat dalam rangka pelayanan perbedaan individual.

e) Memupuk disiplin belajar dan suasana belajar yang demokratis dan kekeluargaan, musyawarah dan mufakat.

f) Membina dan memupuk kerja sama antara sekolah dan masyarakat dan hubungan antara guru dan orang tua peserta didik, yang bermanfaat dalam mendidik peserta didik.

g) Pembelajaran dan belajar dilaksanakan secara realistik dan konkrit, sehingga mengembangkan pemahaman dan berpikir kritis serta menghindari terjadinya verbalisme.

h) Pembelajaran dan kegiatan belajar menjadi hidup sebagaimana halnya kehidupan dalam masyarakat yang penuh dinamika.

Dengan melihat beberapa manfaat pembelajaran aktif di atas dapat diketahui bahwa pembelajaran aktif membuat peserta didik untuk berpendapat, terjadi timbal balik antara guru dengan peserta didik, terjadi kerja sama di dalam kelas, peserta didik menjadi disiplin dan peserta didik terlibat langsung secara intelektual dan emosional dalam proses pembelajaran. Jadi dengan pembelajaran aktif diharapkan peserta didik dapat benar-benar aktif selama proses pembelajaran berlangsung. 
c. Berdasarkan hasil uji korelasi antara pembelajaran Contextual Teaching and Learning di MTs Puteran dengan keaktifan belajar peserta didik, dapat dijelaskan bahwa hasil analisis data setelah dilakukan pengelolaan, nilai thitung lebih besar dari pada ttabel ( $t_{\text {hitung }} 3,26 \geq t_{\text {tabel }} 1,72$ ). Sehingga $H_{\alpha}$ diterima dan $H_{0}$ ditolak. Artinya, bahwa pembelajaran Contextual Teaching and Learning berpengaruh secara positif dan signifikan terhadap peningkatan keaktifan belajar peserta didik.

Selanjutnya, korelasi antara variabel X dan variabel Y berdasarkan harga rs sebesar 0,57 maka berada pada klasifikasi cukup. Hal ini berarti Contextual Teaching and Learning di MTs Puteran pada mata pelajaran Aqidah Akhlak memiliki pengaruh terhadap keaktifan belajar peserta didik. Selanjutnya, derajat determinasi pengaruh antara variabel $\mathrm{X}$ dengan variabel $\mathrm{Y}$ adalah sebesar $32,49 \%$, hal ini menunjukan bahwa keaktifan belajar peserta didik ditentukan oleh model pembelajaran Contextual Teaching and Learning sebesar 32,49\%, sedangkan faktor lain yang mempengaruhi keaktifan belajar peserta didik adalah $100 \%-32,49 \%=67,51 \%$.

\section{Pembahasan}

Dari hasil wawancara ada beberapa faktor yang mempengaruhi kekatifan belajar peserta didik yaitu pertama faktor orang tua, orang tua dalam keluarga sangat menentukan juga mereka adalah mitra para guru dalam bekerja sama untuk tujuan tersebut. Orang tua tidak cukup puas hanya menyerahkan urusan dan tanggung jawab ini kepada guru, kedua faktor lingkungan masyarakat, lingkungan masyarakat tempat berdomisili peserta didik mencara undur yang turut dipertimbangkan dalam proses pembentukan keaktifan belajar peserta didik, karena peserta didik bagian ataupun warga dari dari suatu masyarakat.

Hasil penelitian ini dapat menjelaskan bahwa pelaksanaan pembelajaran Contextextual Teaching and Learning di MTs Puteran akan mengakibatkan meningkatnya kekatifan belajar peserta didik. Karena itu, untuk menciptakan pembelajaran Contextual Teaching and Learning baik diperlukan peran guru yang juga mengerti mengenai pembelajaran Contextual Teaching and Learning.

Penerapan model Pembelajaran CTL di MTS Puteran merupakan bentuk upaya perbaikan kualitas pembelajaran yang menkankan pada keaktifan dan kemandirian siswa dalam belajar akidah ahlak. Penerapan metode ini sangat memungkinkan dan memeberikan pengaruh besar terhadap keaktifan anak untuk menegmbangkan potensi diri dan memahami mata pelajaran Aqidah Akhlak sehingga tercapainya tujuan pembelajaran yaitu, mengembangkan potensi dan kemampuan anak untuk menajdi manusia yang bertaqwa kepada Tuhan yang Maha Esa. 


\section{SIMPULAN}

Dengan berdasarkan kepada pembahasan, pengelolaan dan analisis data yang dilakukan maka dapat diambil simpulan sebagai berikut: penggunaan model pembelajaran Contextual Teaching and Learning berada pada klasifikasi cukup, keaktifan belajar peserta didik berada pada klasifikasi rendah, pengaruh penggunaan model pembelajaran Contextual Teaching and Learning (CTL) terhadap keaktifan belajar peserta didik pada mata pelajaran Aqidah Akhlak berada pada klasifikasi cukup.

Saran yang dapat diberikan adalah sebagai berikut: (1) Bagi sekolah, hasil penelitian ini diharapkan dapat memberikan sumbangan dalam meningkatkan efektifitas proses pembelajaran. Diharapkan pembelajaran Contextual Teaching and Learning dapat diterapkan bukan hanya dalam mata pelajaran Aqidah Akhlak saja, tetapi dalam semua mata pelajaran, (2) Bagi segenap pendidik di Madrasah Tsanawiyah Puteran, berdasarkan hasil penelitian yang dilakukan di MTs Puteran bagi guru disekolah diharapkan dapat menerapkan model Contextual Teaching and Learning dengan baik dalam pelaksanaan kegiatan belajar mengajar yang dapat meningkatkan kemampuan peserta didik dalam evaluasi hasil belajar peserta didik, hendaknya pembelajaran dirancang sedemikian rupa dan memperkaya variasi mengajar, hal ini mengantisipasi kejenuhan yang dialami peserta didik. Dalam upaya mencapai kualitas hasil belajar mengajar, diharapkan kepada guru untuk melatih keterampilan proses kepada peserta didik dengan memberikan kesempatan kepada peserta didik untuk berperan dan juga diharapkan guru lebih bisa memilih metode atau model pembelajaran yang lebih bervariasi atau media yang cocok sesuai dengan karakter peserta didik dan jenis materi yang diajarkan. (3) Bagi peserta didik, untuk lebih aktif lagi dalam kegiatan pembelajaran serta membiasan diri untuk berdiskusi, belajar dan bekerja secara kelompok.

\section{DAFTAR PUSTAKA}

Alfabeta Tim. (2015). Pedoman Penulisan Karya Tulis Ilmiah. Fakultas Tarbiyah.

Hadiyanta, Nur. (2013). "Penerapan Model Pembelajaran Contextual Teaching and Learning (CTL) untuk Meningkatkan Hasil Belajar PKn Peserta Didik Kelas X di MAN Popongan Kabupaten Klaten”. Kependidikan, Vol. 43, No. 01.

Hamalik, Oemar. (2005). Proses Belajar Mengajar. Jakarta : Bumi Aksara.

Hartono. (2008). Metode Pembelajaran Aktif. Yogyakarta.

Johson dalam Kunandar. (2007). Implementasi Kurikulum Tingkat Satuan Pendidik dan Guru Profesional. Jakarta : Rajawali Press.

Rahayu, Mutiara. (2015). Pengaruh Model Pembelajaran Contextual Teaching and Learning (CTL) terhadap Keaktifan Peserta Didik Kelas IV Pada Mata Pelajaran PKN di SD Negeri Warungbambu". Pendidikan Sekolah Dasar, Vol. 03, No.01.

Ramayulis. (2012). Metodelogi Pendidikan Agama Islam. Jakarta : Kalam Mulia.

Sagala, Syaiful. (2010). Supervisi Pembelajaran dalam Proses Pendidikan. Bandung : Alfabeta. 
Sanjaya, Wina. (2013). Strategi Pembelajaran Berorientasi Standar Proses Pendidikan. Jakarta : Kencana Media Group.

Sinar. (2018). Metode Active Learning : Upaya Peningkatan Keaktifan dan Hasil Belajar

Siswa. Yogyakarta : CV Budi Utama.

Sugiyono. (2010). Metode Penelitian Kuantitatif, Kualitatif dan $R \& D$. Bandung : Alfabeta.

Trianto. (2010). Mendesain Model Inofatif-Progresif. Jakarta: Kencana Media Group.

Usman, Raja. (2017). "Penggunaan Metode Pembelajaran Konstektual (Contextual Teaching and Learning) Untuk Meningkatkan Aktivitas dan Hasil Belajar IPS Siswa Kelas III A SDN 02 Kundur". Vol.06, No.02.

Wawan. (tt). (2015). Desain Penelitian Kuantitatif. Tasikmalaya. Latifah Press. (tt). (2015). Pengantar Statistika Pendidikan. Tasikmalaya. Latifan Press. 